\title{
Changes in forest soil properties and spruce stands characteristics after dolomite, magnesite and serpentinite fertilization
}

\author{
Ewa Błońska ${ }^{1}$ - Stanisław Małek ${ }^{2}$ - Kazimierz Januszek ${ }^{1}$ Józef Barszcz ${ }^{2}$. \\ Tomasz Wanic ${ }^{1}$
}

Received: 18 February 2015/Revised: 11 July 2015 / Accepted: 22 July 2015/Published online: 6 August 2015

(C) The Author(s) 2015. This article is published with open access at Springerlink.com

\begin{abstract}
We have to deal with spruce dieback in recent years in Europe. Fertilization can be used to reduce susceptibility to forest dying through improving the chemical properties of soil. The aim of this study was to assess the condition of soil and spruce stand after dolomite, magnesite and serpentinite fertilization. The fertilization was used to sustain a stable condition and extended the life of spruce stands by several years which allows the reconstruction of the stand. The experimental plots were set up in the areas of two Carpathian nappes, differing in terms of lithological deposits, in Wisła and Ujsoły Forest Districts. Fertilization improves the chemical properties and enzymes activity of soil. The used fertilization variants did not cause inhibition of soil enzymatic activity. The effect of liming is visible mainly in the humus horizon, and in the deeper mineral soil, a significant change was not found. Heavy metals, mainly nickel introduced with serpentinite, did not inhibit the activity of enzymes. As a result of fertilization, the process of dying spruce was delayed. Three years after fertilization, a clear improvement in the chemistry of spruce needles was not recorded.
\end{abstract}

Communicated by Agustín Merino.

Ewa Błońska

eblonska@ar.krakow.pl

1 Department of Forest Soil, Institute of Forest Ecology and Silviculture, Faculty of Forestry, University of Agriculture in Krakow, Al. 29-go Listopada 46, 31-425 Kraków, Poland

2 Department of Forest Ecology and Reclamation, Institute of Forest Ecology and Silviculture, Faculty of Forestry, University of Agriculture in Krakow, Al. 29-go Listopada 46, 31-425 Kraków, Poland
Keywords Dehydrogenases activity · Urease activity · LAI

\section{Introduction}

We have to deal with spruce dieback in recent years in Europe. People's activities have increasingly led to the acidification of terrestrial ecosystems (Reuss and Johnson 1986). Fertilization can be used to reduce susceptibility to forest dying through improving the chemical properties of soil. Fertilization of forest land can be a way to prevent weakening of the forest stands. Thus, it is important to know the basic issues related to the effects of fertilization on the soil properties and forest stands. The use of liming to reduce acidity of forests soils was recommended in Germany as far back as of the end of the last century (Deroma et al. 2000). Numerous liming experiments were established in Finland and Sweden (Viro 1951). The changes in soil chemistry after liming were demonstrated by Kruetzer (1995). Liming was used to raise soil $\mathrm{pH}$ and to increase concentrations of $\mathrm{Ca}$ and $\mathrm{Mg}$ (Saarsalmi et al. 2011; 2014).

In the area of the Beskidy Mountains, we noticed increasing share of decaying spruce stands or a potential risk of its occurrence in the future (Małek 2010; Małek et al. 2012). The aim of fertilization by dolomite, magnesite and serpentinite is to delay dying of spruce stands. A significant improvement in the chemistry of spruce needles after applying fertilizer was not expected. Sustaining the existing forest stands as a result of fertilization will allow their reconstruction. The published data based on field experiments have not presented short-term effects of liming on survival and growth trees. Sikström (2005) investigated the survival of Picea abies seedlings during the first 
11 growing seasons after liming. Many researchers (Børja and Nilsen 2009; Jonard et al. 2010) have studied the longterm effects of liming on forest stands.

Badalucco et al. (1992), Liu (2004) and Mijangos et al. (2006) studied the effect of fertilization on soil fertility by investigating soil enzymatic activity. Ajwa et al. (1999) noted that biological parameters have a considerable value as early and sensitive indicators of the changes in soil properties induced by different management strategies and fertilization. In comparison with the biological and biochemical properties, the physical and chemical ones constitute a less sensitive indicator of changes that occur in soil (Błońska and Januszek 2013). The biological indicators, such as enzymatic activity and microbiological biomass, seem to be better indicators since they respond much faster to both natural and anthropogenic factors in comparison with other variables (Garciá et al. 2000). Clivot et al. (2012) study contributes to confirming the usefulness of microbial indicators by providing a common indicator of liming effects 4 years later. The dehydrogenases represent enzymes which provide information about environmental conditions and microbial activity in the soil. The activity of dehydrogenases is extremely important in organic matter dynamics (Paradelo and Barrales 2009). Urease is an enzyme that catalyzes the hydrolysis of urea into carbon dioxide and ammonia. The urease activity like dehydrogenase activity reacts promptly to changes in the use of soil (Gil-Sotres et al. 2005). Badalucco et al. (1992) observed that addition of lime to acid forest soils has the beneficial effects on microbial biomass and microbial activity. Dehydrogenase activity was increased by liming.

The aim of this study was to assess soil and spruce stand condition after dolomite, magnesite and serpentinite fertilization. The fertilization was used to sustain a stable condition and extended the life of spruce stands by several years which allows the reconstruction of the stand. We hypothesized that: (1) fertilization improves the chemical properties and enzymes activity and (2) by improving soil properties, the dieback of stand can be postponed and its condition improved.

\section{Materials and methods}

\section{Study area and experimental design}

The experimental plots were set up in the areas of two Carpathian nappes, differing in terms of lithological deposits. The Magura Nappe (Ujsoły Forest District) is built of thin-bedded sandstone with a share of clay slate inclusions, with meso-/eutrophic soils that are more buffered and resistant to degradation. The Silesian Nappe (Wisła Forest District) in the range of Barania Góra
Mountain, built of the lower Istebna layers, consists of thick-bedded sandstones and conglomerates, producing sandy-loam, gravelly cobbly waste mantle with oligotrophic soils. The Haplic Podzol soil built of very stony, coarse sandy-loam stratiform of very cobbly sandy loam with mor type of humus was noted on the experimental plots in Wisła. The Endoeutric Cambisol built of loam deposition on very cobbly clay loam and very cobbly silty clay loam with the moder type of humus was noted on the experimental plots in Ujsoły. A more comprehensive description of the soils and results of soil analysis 1 year after fertilization in the Wisła and Ujsoły research plots was presented by Januszek et al. (2011). The results of soil analysis 2 years after fertilization in the Wisła and Ujsoły research plots were presented by Małek et al. (2014).

The experiment was carried out on plots $(10 \times 10 \mathrm{~m})$ with 5-m insulating strips between plots. Fertilizers were added in autumn 2008. The 4 treatments were used: $\mathrm{C}$ control no fertilizer; D dolomite $(4000 \mathrm{~kg} / \mathrm{ha}$ in the Wisła Forest District; $2000 \mathrm{~kg} / \mathrm{ha}$ in the Ujsoły Forest District); M magnesite (4000 kg/ha in the Wisła Forest District; $2000 \mathrm{~kg} / \mathrm{ha}$ in the Ujsoły Forest District); S serpentinite (4000 kg/ha in the Wisła Forest District; $2000 \mathrm{~kg} / \mathrm{ha}$ in the Ujsoły Forest District). Fertilizer containing fine particles ( $\varnothing 0-1 \mathrm{~mm}$ ). The composition of used fertilizers is presented in Table 1.

\section{Soil sampling and analysis}

Soil samples were collected on the experimental sites in Wisła and in Ujsoły in September 2011. On the experimental sites in Wisła, from every plot $(10 \times 10 \mathrm{~m}$ each $)$ two aggregate samples were collected from 4 holes randomly placed within plot with the size of $20 \times 20 \times 20 \mathrm{~cm}$. The first sample was obtained from the organic horizon (without further sub-horizons), and one was taken from the AE horizon down to $20 \mathrm{~cm}$. The soil samples on the experimental sites in Ujsoły were obtained from the depth of $0-10,10-20 \mathrm{~cm}$, respectively. The soil for determining chemical and physical properties was collected after removal of the litter layer. In all the cases, samples for the research were collected from 4 sub-stands of the soil horizon. Samples were returned to the laboratory for analysis. The collected samples were first dried at room temperature and then sieved through a 2-mm sieve. The sample parameters and method of analysis are presented in Table 2.

\section{Enzyme activities}

The dehydrogenase activity was determined using Lenhard's method according to the Casida procedure. The method is known as "the TTC" test, and $3 \%$ solution of 


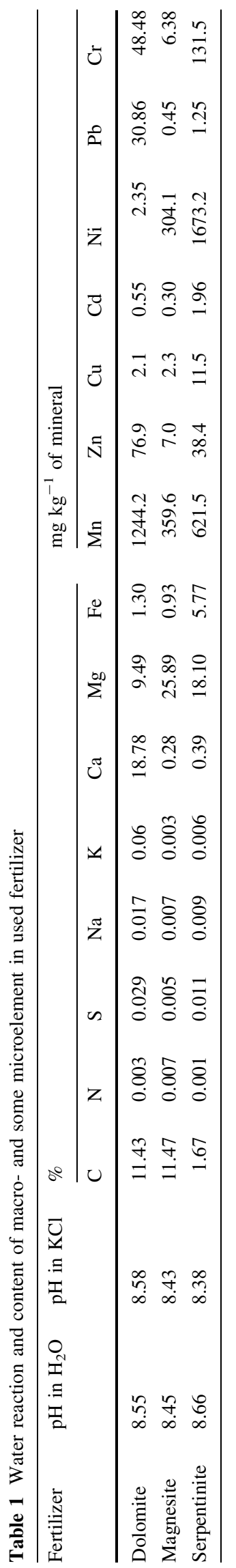

triphenyltetrazolium chloride (TTC) was used. For washing out the formazan gathered in soil, ethyl alcohol contaminated with methanol was used (Alef and Nannipieri 1995). Urease activity was marked with Tabatabai and Bremner's method (1972) (Alef and Nannipieri 1995). In each cumulative sample of the natural moisture after sieving through a sieve with an aperture of $2 \mathrm{~mm}$, the activity of enzymes was determined, in three repetitions. Dehydrogenase activity was determined in samples collected in 2011. Urease activity was determined in samples collected in 2010.

\section{Stand characteristics}

On experimental plots, trees were numbered, the diameter at breast height and tree heights of all the trees were measured. Trees were evaluated according to the IUFRO classification and the percentage of thinning canopy and the leaf area index (LAI) were determined using LAI 2000 from LI-COR apparatus. According to the methodology of ICP Forest Manual (1998), branches of the seventh whorl from the top of the three standing spruce sample trees were cut. Trees were selected at random. Current and 2-year-old needles were taken for chemical analyzes. $\mathrm{N}$ and $\mathrm{S}$ were determined with CNS 2000 LECO elemental analyzer, and $\mathrm{K}, \mathrm{Mg}, \mathrm{Ca}$, Ni with Thermo Scientific iCAP 6000 ICP OES Spectrometer after wet mineralization with $\mathrm{HNO}_{3}$ and $\mathrm{HClO}_{4}$ in 1:4.

\section{Statistical analysis}

Statistical data analysis was performed using the program Statistica 10. In order to reduce the number of variables in statistical data set and visualize multivariate data set, PCA method was used. PCA method was also used in order to interpret factors depending on the kind of data set. In PCA analysis, the physicochemical properties and enzymes activity of soil were used. Differences between the mean values were evaluated with the nonparametric KruskalWallis test.

\section{Results}

\section{Physicochemical properties of soils}

A significant impact of used fertilization variant on the $\mathrm{pH}$ in surface horizon (Ofh and OhA) of soil was noted. The $\mathrm{pH}$ increase depended on the fertilization variant, the dose of fertilizer and soil properties (Table 3). A lower concentration of exchangeable aluminum was found in the horizons of soils with fertilization compared to the control. Higher concentration of exchangeable calcium in all the 
Table 2 Sample parameters and method of analysis

\begin{tabular}{ll}
\hline Soil pH & Methods \\
Total $\mathrm{C}\left(\mathrm{C}_{\mathrm{T}}\right)$ and Total $\mathrm{N}\left(\mathrm{N}_{\mathrm{T}}\right)$ & $\begin{array}{c}\text { Determined potentiometrically, in } \mathrm{H}_{2} \mathrm{O} \text { and } 1 \mathrm{M} \mathrm{KCl} \mathrm{dm}^{-3} \text { solutions, with soil-to-solvent } \\
\text { proportion of } 1: 2.5 \text { for mineral soils and } 1: 5 \text { for organic soils }\end{array}$ \\
Exchangeable Aluminum $\left(\mathrm{H}_{\mathrm{Al}}\right)$ & $\mathrm{CNS} 2000 \mathrm{LECO}$ elemental analyzer \\
Calcium $\left(\mathrm{Ca}^{2+}\right)$, Magnesium $\left(\mathrm{Mg}^{2+}\right)$ & Sokołow method \\
& In a $1 \mathrm{M} \mathrm{CH}_{3} \mathrm{COONH}$ extract of pH 7.0 as determined with a Thermo \\
Content of $\mathrm{Cr}$ and $\mathrm{Ni}$ & Scientific iCAP $6000 \mathrm{ICP}$ OES Spectrometer \\
\hline
\end{tabular}

horizons of soil with dolomite fertilization (D) of the plot was noted. After magnesite fertilization of the soil in Wisła, the concentration of exchangeable calcium in the mineral horizon tended to decrease. The applied fertilization affected the concentration of exchangeable magnesium in soil horizon. In the Ofh and AE horizon of soil in Wisła, the tendency to decrease the concentration of carbon and nitrogen in the fertilization variants compared to the control was noted. Higher concentrations of nickel were found in the serpentinite variant and lower in control variants and dolomite and magnesite treatment (Table 3$)$. In the organic horizon, a significant difference $(<0.05)$ in soil properties: $\mathrm{pH}, \mathrm{Al}, \mathrm{Ca}, \mathrm{Mg}, \mathrm{Ni}$ and $\mathrm{Cr}$ content compared to the control, was noted (Table 3 ).

\section{Enzyme activities}

Dehydrogenase activity increased in all the fertilization variants compared with the control in organic horizons. A less pronounced increase in dehydrogenase activity was noted in the humus mineral horizons. A strong increase in urease activity was noted in the case of dolomite and magnesite fertilization. Serpentinite fertilization had the least significant influence on urease activity. The strongest increase in urease activity was reflected in the organic horizon (Table 3). The activity of enzymes was strongly associated with the $\mathrm{pH}$. It was found that the enzyme activity of the studied soil increased with the $\mathrm{pH}$ and cations content. The activity of enzymes negatively correlated with the $\mathrm{Al}$ content (Fig. 1). Significant differences were noted in the organic horizon on the Wisła plot in the dehydrogenase activity (Table 3 ).

\section{PCA analysis}

One year after fertilization, the influence of magnesite and dolomite was observed, whereas 3 years after fertilization, the impact of serpentinite fertilizer additionally was noted (Fig. 1,2). The impact of fertilization was reflected in the organic horizon (Ofh), and the lack of enzyme activity stimulation after fertilization in mineral horizons (AE) was noticed. In the organic horizon in Wisła 3 years after fertilization, factors 1 and 2 explained variances of the variables in $64.97 \%$ (Fig. 1). Factor 1 which explains $41.18 \%$ of the variation is strongly associated with $\mathrm{pH}, \mathrm{Al}$ and $\mathrm{Mg}$ content. Factor 2 is strongly correlated with quality of organic matter (ratio $\mathrm{C} / \mathrm{N}$ ). This factor explains $26.14 \%$ of the variance of the examined properties. In organic horizon in Ujsoły, two main factors were selected that have impact on the variances of the variables. Factor 1 and 2 explained $73.75 \%$ variation of the examined properties. Factor 1 is associated with $\mathrm{pH}$ and $\mathrm{Al}$ content. Factor 2 is correlated with $\mathrm{C}, \mathrm{N}$ content and $\mathrm{C} / \mathrm{N}$ ratio (Fig. 2).

\section{Stands characteristic}

A greater and more diverse percentage of trees were fallen in Ujsoły, while in Wisła the dieback was less significant and less diversified (Table 4). The sown fertilizer had a positive effect on stands in Ujsoły, clearly slowing down the process of tree dieback, especially in the magnesite variant. The use of magnesite had a greater impact on slowdown of thinning canopy in spruce stands. Stand leaf area index (LAI) has also changed, which was influenced by the size of the dead trees and thinning canopy. The ranges were about $0.5-0.6$ units (Wisła) and 0.2-0.5 units (Ujsoły) (Table 4).

In the chemical composition of spruce needles, the increase in concentrations of potassium from plots fertilized with dolomite and magnesium was observed. In needles from 2011 compared to 2009 in Ujsoły, nitrogen content decreased in all the variants, while in the Wisła area it occurred only on the fertilized variants (Table 5). In relation to the limit values and in the proportions between elements, the situation varied. In 2011, in Ujsoły it was exceeded only in 4 out of 24 possible variants: with magnesite (for $\mathrm{S}: \mathrm{Ca}, \mathrm{N}: \mathrm{Ca}$ and $\mathrm{K}: \mathrm{Ca}$ ) and dolomite $(\mathrm{K}: \mathrm{Ca})$. In Wisla, the amount of exceeded value increased to 11 


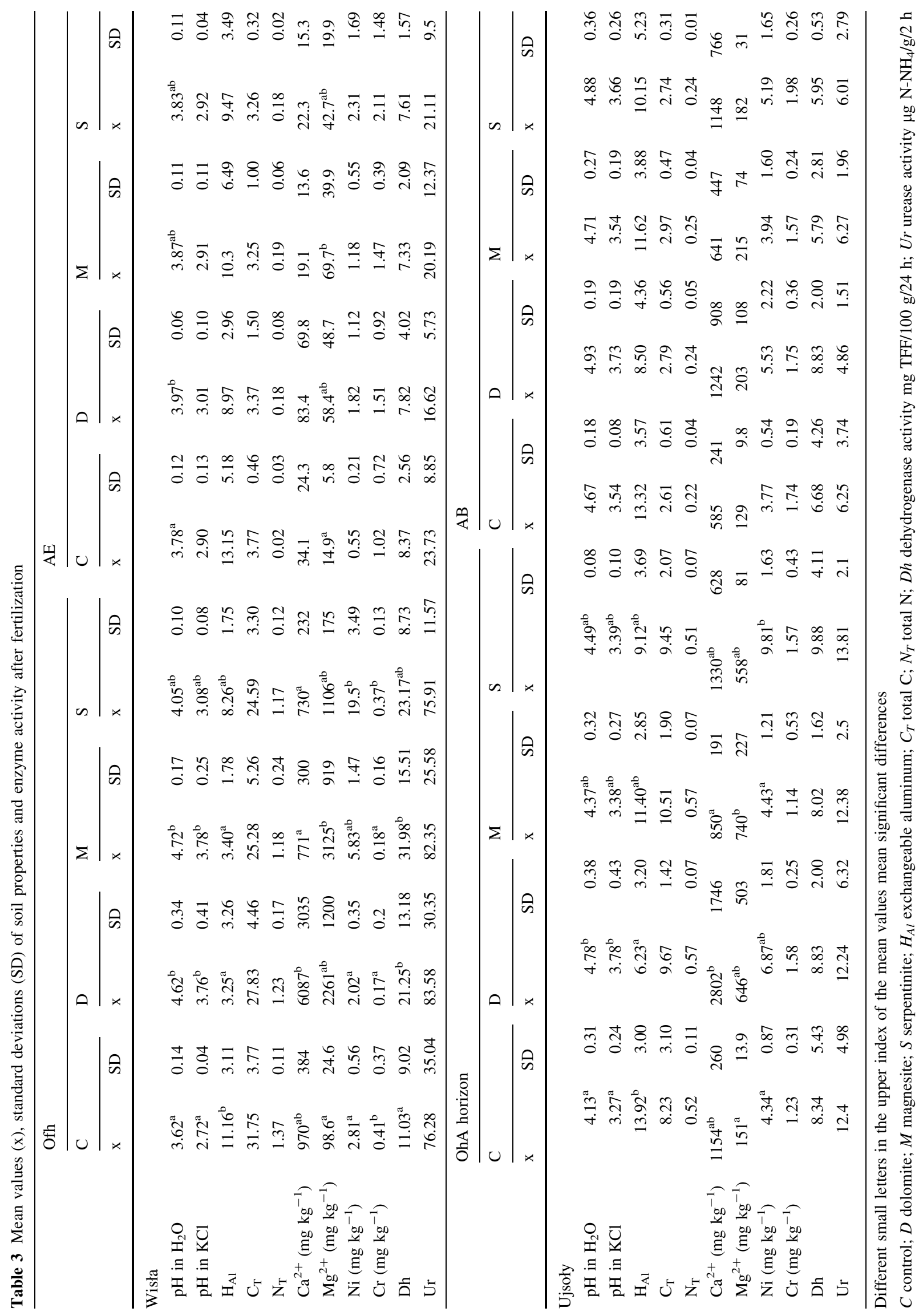



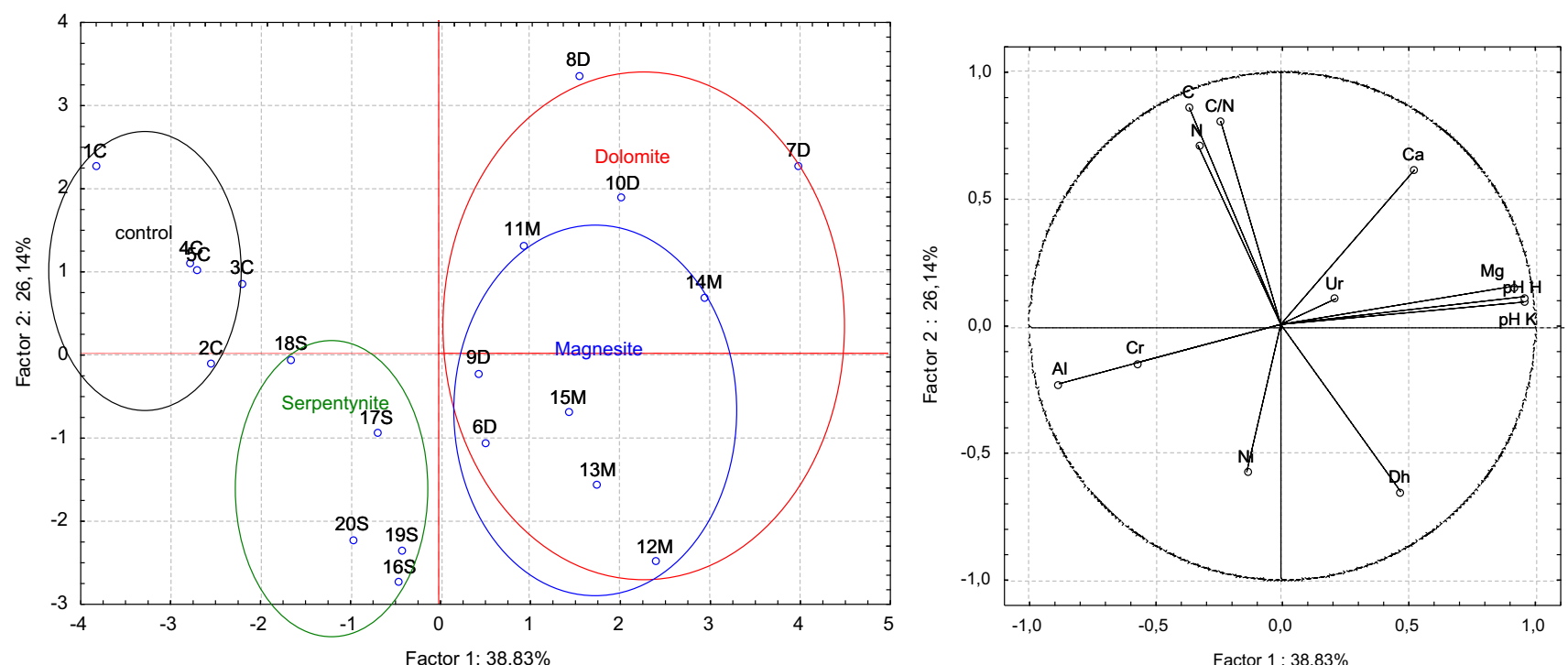

Fig. 1 Factorial plan and projection of variables in the soil properties in organic horizon (Ofh) on the factor plane $1 \times 2$ in Wisła after fertilization
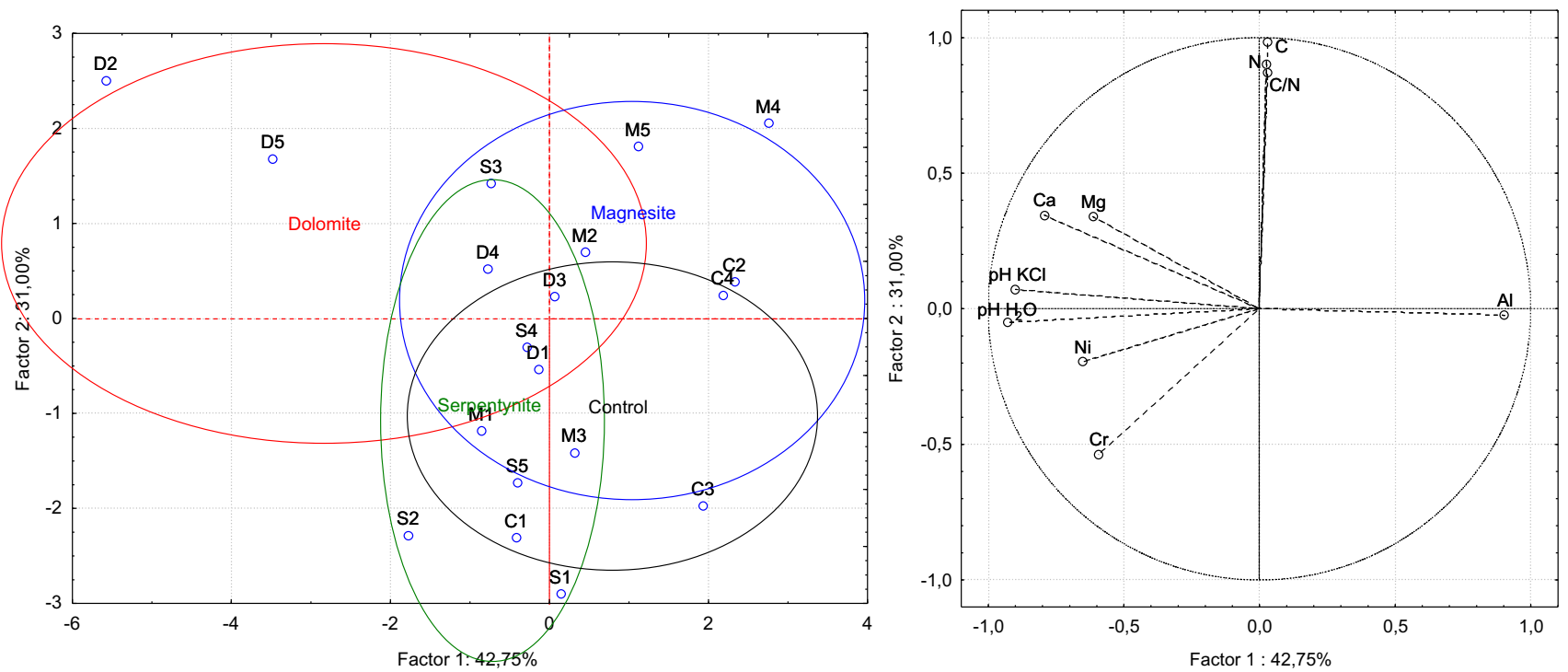

Fig. 2 Factorial plan and projection of variables in the soil properties in organic horizon $(\mathrm{OhA})$ on the factor plane $1 \times 2$, in Ujsoly after fertilization

mainly for $\mathrm{S}: \mathrm{Ca}$ and $\mathrm{N}: \mathrm{Ca}$ and $\mathrm{K}: \mathrm{Ca}$. The levels of the analyzed microelements in spruce needles were differed. The content of $\mathrm{Ni}$ in the needles of spruce in both periods was higher on Ujsoły plot (Table 5).

\section{Discussion}

The expected positive influence of fertilization on the deacidification of soil and increase in $\mathrm{Ca}$ and $\mathrm{Mg}$ supply of the soil were noted. Following fertilization, an increase in $\mathrm{pH}$ and a decrease in the concentration of exchangeable aluminum were observed. The great increase in $\mathrm{pH}$ and decrease in exchangeable aluminum were recorded in organic horizons. In $\mathrm{AE}$ and $\mathrm{AB}$ horizon, the difference was less conspicuous. Among the used fertilizers (dolomite, magnesite and serpentinite), serpentinite fertilization provided a significant enhancement of soil in magnesium over a long period of time because it has low susceptibility to weathering and low $\mathrm{pH}$ increase. The use of slowly released fertilizer containing macro- and micronutrients was more favorable for improving nutrient deficiencies than rapidly soluble fertilizers (Flückiger and Braun 1995). Liming is known not only to increase $\mathrm{pH}$, base saturation, 
Table 4 Changes in the number of trees and their diameter at breast height, condition of trees on the basis of selected features of IUFRO classification, thinning canopy and the leaf area index in years 2008-2011

\begin{tabular}{|c|c|c|c|c|c|c|c|c|}
\hline \multirow{3}{*}{$\begin{array}{l}\text { Variant of } \\
\text { fertilization }\end{array}$} & \multirow[t]{3}{*}{ Species } & \multirow{2}{*}{\multicolumn{2}{|c|}{ Changes in number of trees }} & \multirow{3}{*}{$\begin{array}{l}\text { Increase in diameter } \\
\text { at breast height } \\
\%\end{array}$} & \multicolumn{4}{|c|}{ Changes in the selected features } \\
\hline & & & & & \multirow{2}{*}{$\begin{array}{l}\mathrm{V} \\
\%\end{array}$} & \multirow[t]{2}{*}{ DT } & \multirow[t]{2}{*}{$\mathrm{TC}$} & \multirow[t]{2}{*}{ LAI } \\
\hline & & Survived $\%$ & Disappeared \% & & & & & \\
\hline \multicolumn{9}{|l|}{ Wista } \\
\hline \multirow[t]{2}{*}{$\mathrm{C}$} & $\mathrm{Be}$ & 93 & 7 & +3.3 & -3.0 & -0.2 & n.d. & -0.6 \\
\hline & $\mathrm{Sp}$ & 84 & 16 & +2.0 & +1.5 & +0.3 & +18.7 & \\
\hline \multirow[t]{2}{*}{$\mathrm{D}$} & $\mathrm{Be}$ & 88 & 12 & +5.7 & -6.1 & -0.5 & n.d. & -0.6 \\
\hline & $\mathrm{Sp}$ & 79 & 21 & +2.5 & -1.0 & +0.1 & +12.4 & \\
\hline \multirow[t]{2}{*}{ M } & $\mathrm{Be}$ & 94 & 6 & +3.8 & -5.9 & -0.5 & n.d. & -0.5 \\
\hline & $\mathrm{Sp}$ & 80 & 20 & +2.4 & -1.2 & -0.2 & +6.3 & \\
\hline \multirow[t]{2}{*}{ S } & $\mathrm{Be}$ & 98 & 2 & +2.9 & -6.0 & -0.3 & n.d. & -0.6 \\
\hline & $\mathrm{Sp}$ & 82 & 18 & +2.5 & -0.7 & -0.1 & +10.9 & \\
\hline \multicolumn{9}{|l|}{ Ujsoty } \\
\hline $\mathrm{C}$ & $\mathrm{Sp}$ & 67 & 33 & +0.5 & +1.7 & +0.2 & +15.9 & -0.5 \\
\hline D & $\mathrm{Sp}$ & 71 & 29 & +0.6 & -0.3 & +0.1 & +5.3 & -0.3 \\
\hline M & $\mathrm{Sp}$ & 90 & 10 & +1.1 & -0.7 & 0.0 & +2.4 & -0.2 \\
\hline$S$ & $\mathrm{Sp}$ & 78 & 22 & +0.5 & -0.2 & 0.0 & +4.6 & -0.3 \\
\hline
\end{tabular}

$C$ control variant, $D$ dolomite fertilization, $M$ magnesite fertilization, $S$ serpentinite fertilization, $B e$ beech, $S p$ spruce, $V$ vitality, $D T$ development trend; $T C$ thinning canopy, $L A I$ leaf area index, n.d. not determined

Table 5 Chemical composition of needles of spruce in 2009 and 2011

\begin{tabular}{|c|c|c|c|c|c|c|c|c|c|}
\hline Variant of fertilization & $\mathrm{N}(\%)$ & $\mathrm{S}(\%)$ & $\mathrm{K}(\%)$ & $\mathrm{Ca}(\%)$ & $\operatorname{Mg}(\%)$ & $\mathrm{S}: \mathrm{Ca}$ & $\mathrm{N}: \mathrm{Ca}$ & $\mathrm{K}: \mathrm{Ca}$ & $\mathrm{Ni}(\mathrm{ppm})$ \\
\hline \multicolumn{10}{|l|}{ Wista (2009) } \\
\hline $\mathrm{C}$ & 1.15 & 0.05 & 0.59 & 0.29 & 0.05 & 0.2 & 4.0 & 2.0 & 6.0 \\
\hline D & 1.21 & 0.04 & 0.67 & 0.23 & 0.07 & 0.2 & 5.2 & 2.9 & 6.0 \\
\hline M & 1.18 & 0.04 & 0.49 & 0.34 & 0.08 & 0.1 & 3.5 & 1.4 & 7.9 \\
\hline S & 1.11 & 0.05 & 0.49 & 0.13 & 0.05 & 0.4 & 8.6 & 3.8 & 7.9 \\
\hline \multicolumn{10}{|l|}{ Wista (2011) } \\
\hline $\mathrm{C}$ & 1.22 & 0.10 & 0.48 & 0.21 & 0.06 & 0.4 & 5.7 & 2.3 & 1.0 \\
\hline D & 1.08 & 0.08 & 0.52 & 0.16 & 0.07 & 0.5 & 6.7 & 3.2 & 1.3 \\
\hline M & 0.88 & 0.07 & 0.47 & 0.06 & 0.05 & 1.2 & 15.1 & 8.0 & 2.0 \\
\hline$S$ & 0.98 & 0.08 & 0.49 & 0.07 & 0.04 & 1.1 & 13.8 & 6.9 & 1.3 \\
\hline \multicolumn{10}{|l|}{ Ujsoty (2009) } \\
\hline C & 1.13 & 0.12 & 0.51 & 0.38 & 0.09 & 0.3 & 2.9 & 1.3 & 10.3 \\
\hline D & 1.11 & 0.14 & 0.68 & 0.53 & 0.10 & 0.3 & 2.1 & 1.3 & 14.3 \\
\hline M & 1.14 & 0.11 & 0.64 & 0.62 & 0.09 & 0.2 & 1.8 & 1.0 & 7.9 \\
\hline S & 1.12 & 0.14 & 0.53 & 0.35 & 0.10 & 0.4 & 3.2 & 1.5 & 10.6 \\
\hline \multicolumn{10}{|l|}{ Ujsoty (2011) } \\
\hline $\mathrm{C}$ & 0.94 & 0.07 & 0.44 & 0.26 & 0.10 & 0.3 & 3.6 & 1.7 & 8.7 \\
\hline D & 0.98 & 0.08 & 0.52 & 0.21 & 0.08 & 0.4 & 4.7 & 2.5 & 5.3 \\
\hline M & 0.97 & 0.08 & 0.51 & 0.15 & 0.08 & 0.5 & 6.5 & 3.4 & 9.7 \\
\hline S & 0.96 & 0.08 & 0.48 & 0.28 & 0.09 & 0.3 & 3.5 & 1.7 & 5.8 \\
\hline
\end{tabular}

$C$ control variant, $D$ dolomite fertilization, $M$ magnesite fertilization, $S$ serpentinite fertilization 
exchangeable $\mathrm{Ca}$ and $\mathrm{Mg}$, but also to increase microbial activity (Persson et al. 1990; Kreutzer 1995; Lorenz et al. 2001).

In the surface horizon of studied soils, the $\mathrm{pH}$ value was increased as a result of sowing carbonate fertilizers. This has contributed to improving the microbial activity, which was reflected in an increase in the activity of dehydrogenase and urease. In the case of both enzymes, their activity increased while exchangeable alkaline cations increased too. Enzyme activities can be affected by factors such as temperature, moisture, $\mathrm{pH}$, nutrient availability (Baldrian et al. 2012). Soil $\mathrm{pH}$ affects the activity of soil enzymes through its controls on microbial enzyme production, availability of substrates and enzymatic co-factors (Tabatabai 1994). The increased activity may be due to the increase in the number of microorganisms and microbial activity. According the Xiaoguang et al. (2011), the increased soil enzyme activities of fertilization-treated soils may be the consequence of both microbial growth and stimulation of microbial activity by enhanced resource availability.

No negative impact of used serpentinite fertilizer on the enzymatic activity of studied soils in spruce stands shows the absence of toxic concentrations of heavy metals in the soils and indicates the possibility of using this type of fertilizer in forestry. The study of enzymatic activity indicates that heavy metals, mainly nickel brought with serpentinite to soil, did not inhibit the activity of enzymes. Heavy metals can stimulate the activity of soil enzymes in smaller amounts, but they can also act as inhibitors if present in high concentrations (Frankenberger et al. 1983; Wyszkowska et al. 2001). Previous studies showed that soil contamination with high heavy metal content could have a negative impact on soil organisms and consequently on the biochemical activity of soil (Friedlová 2010).

The most rapid organic matter mineralization in soils fertilized with dolomite and magnesite is an additional effect observed in this experiment. Liming is expected to increase soil $\mathrm{C}$ losses, because of lime-induced increases in soil biological activity and therefore rates of soil $\mathrm{CO}_{2}$ respiration (Biasi et al. 2008). Soil enzymes activities are sensor of soil organic matter decomposition since they integrate information about microbial status and soil physicochemical conditions (Sinsabaugh et al. 2008). The increase in enzyme activity was noted in soils with dolomite and magnesite fertilization where loss of organic matter was observed.

The effects of liming (2.0 and 4.0 $\mathrm{Mg} \mathrm{ha}^{-1}$ ) on chemical properties of soil, nutrient concentrations of needles and growth of Scots pine (Pinus sylvestris L.) were investigated by Saarsalmi et al. (2011). Huang et al. (2014) noted the increase in herb biomass and $\mathrm{Mg}$ content in Masson pine needles. The growth rate of Masson pine did not increase possibly because of the limited observation period. In
Wisła and Ujsoły, the conducted fertilization significantly improved soil properties, whereas the poorer condition of forest stands was only slightly improved. The nitrogen content in spruce needles was below the optimal values: according to Arndt et al. (1987), in the range of low values $(<1.31 \% \mathrm{dm})$; according to Zöttl (1990), below the range of the average deficit (1.2-1.3\%); and according to Cape et al. (1990), even in the "visible signs of deficiency" $(0.8-1.3 \%)$. Fertilizers used on research plots generally resulted in the decrease in potassium. Most $\mathrm{K}$ (approx. $0.06 \%$ ) was in dolomite, and in this variant, most potassium in the needles was determined in 2009. Insignificant predominance of this element in 2011 in the Wisła and Ujsoły was maintained. In 2011, the calcium content in both locations declined. According to Arndt et al. (1987), the level of $\mathrm{Ca}$ in spruce needles can be generally defined as high, according to the Zöttl's data (1990)_as the optimal (with the exception of the plot with magnesite-average value of a deficit) and according to Cape et al. (1990) — as the shortage. Concentrations were within the range specified by the Fober (1998) for spruce needles "showing external signs of Ca deficiency." Analyses of needles from 2011 indicate that the $\mathrm{Mg}$ content in the needles is still higher in Ujsoły than in Wisła. In Ujsoły, they remain in the range of optimum values, and in Wisła, in the range of average deficit (Zöttl 1990). According to Arndt et al. (1987), the content of this element in the needles in both locations is in the range "for not showing symptoms spruce deficit." The effect of liming on tree growth is dependent on the soil chemical properties, particularly the deficiency of $\mathrm{Ca}$ and $\mathrm{Mg}$ (Jonard et al. 2010). In addition, the reaction of forest stands to liming can be affected by such factors as tree species and age (Kakei and Clifford 2002). It was reported that lime application had no effects on loblolly pine after 20 years (Torbert and Burger 1984) and Norway spruce and beech after 40 years (Persson et al. 1995). Huber et al. (2006) noted that liming had a relatively insignificant effect on the needle chemistry.

The applied fertilization had a positive impact on the health condition of stand, and it slowed down the process of dying trees especially after using magnesite. It indicated a tendency to improve the viability of trees and their growth compared to the control variant. The sown fertilizer contributed to the slowdown in the thinning canopy, which increased in most variants over the period, but always less than in the control variant. The stand leaf area index (LAI) decreased due to the loss of trees and thinning canopy. On both surfaces, the lowest values of differences in LAI from 2008 to 2011 were noted in magnesite variant. LAI indicator quickly responded to the presence of stress factors in plants (Stenberg et al. 2004). In our study, LAI turned out to be an effective tool for the evaluation of the fertilization effects. 


\section{Conclusions}

1. Fertilization improves the chemical properties and enzymes activity of soil. The used fertilization variants did not cause inhibition of soil enzymatic activity. The $\mathrm{pH}$ increase in organic horizons as a result of the use of carbonate rocks led to the increase in the activity of dehydrogenases and urease in all fertilization variants.

2. The effect of liming is visible mainly in the humus horizon; in the deeper mineral soil, a significant change was not found. The very slow release of soluble ions from the rock fertilizer and a temporary $\mathrm{pH}$ decrease are the cause of the lack of stimulation of the applied fertilizers on the enzyme activity in mineral horizons.

3. Heavy metals, mainly nickel introduced with serpentinite, did not inhibit the activity of enzymes.

4. The results have shown that fertilization caused the increase in soil C losses.

5. The used fertilizer improved the properties of soil, which directly resulted in the improvement of the condition of the stand. As a result of fertilization, the process of dying spruce was delayed. The sown fertilizer had an impact on decreasing spruce canopy opening.

6. Three years after fertilization, a clear improvement in the chemistry of spruce needles was not recorded.

Acknowledgments This work was financed by the State Forests National Forest Holding in Poland within the project: 3/08-Forest management measures improving the growth, nutrition and health conditions in forest regeneration areas and endangered stands in the Beskidy Mountains, with particular emphasis on soil revitalization with dolomites and new multi-component long-acting fertilizers.

Open Access This article is distributed under the terms of the Creative Commons Attribution 4.0 International License (http://crea tivecommons.org/licenses/by/4.0/), which permits unrestricted use, distribution, and reproduction in any medium, provided you give appropriate credit to the original author(s) and the source, provide a link to the Creative Commons license, and indicate if changes were made.

\section{References}

Ajwa HA, Dell CJ, Rice CW (1999) Changes in enzyme activities and microbial biomass of tallgrass prairie soil as related to burning and nitrogen fertilization. Soil Biol Biochem 31:769-777

Alef K, Nannipieri P (1995) Enzyme activities. In: Nannipieri P, Alef $\mathrm{K}$ (eds) Methods in applied Soil microbiology and biochemistry. Academic Press, London

Arndt U, Nobel W, Schweizer B (1987) Bioindikatoren Moeglichkeiten, Grenzen und neue Erkenntnisse. Ulmer Verlag, Stuttgart

Badalucco L, Grego S, Dell'Orco S, Nannipieri P (1992) Effect of liming on some chemical, biochemical, and microbiological properties of acid soils under Spruce (Picea abies L.). Biol Fertil Soils 14:76-83
Baldrian P, Snajdr J, Merhautová V, Dobiásová P, Cajthaml T, Valásková V (2012) Responses of the extracellular enzyme activities in hardwood forest to soil temperature and seasonality and the potential effects of climate change. Soil Biol Biochem $56: 60-68$

Biasi C, Lind SE, Pekkarinen NM, Huttunen JT, Shurpali NJ, Hyvönen NP, Repo ME, Martikainen PJ (2008) Direct experimental evidence for the contribution of lime to $\mathrm{CO}_{2}$ release from managed peat soil. Soil Biol Biochem 40:2660-2669

Błońska E, Januszek K (2013) Usability of enzyme activity in estimation of forest soil quality. Folia For Pol Ser A For 55(1):18-26

Børja J, Nilsen P (2009) Long term effect of liming and fertilization on ectomycorhizal colonization and tree growth in old Scots pine (Pinus sylvestris L.) stands. Plant Soil 314:109-119

Cape JN, Freer-Smith PH, Paterson IS, Parkinson JA, Wolfenden J (1990) The nutritional status of Picea abies (L.) Karst. Across Europe and implications for forest decline. Trees 4:211-224

Clivot H, Pagnout C, Aran D, Devin S, Bauda P, Poupin P, Guérold F (2012) Changes in soil bacterial communities following liming of acidified forests. Appl Soil Ecol 59:116-123

Derome J, Kukkola M, Smlander A, Lehto T (2000) Liming of forest soils. For Cond chang environ 65:328-337

Flückiger W, Braun S (1995) Revitalization of an alpine protective forest by fertilization. Plant Soil 168-169:481-488

Fober H (1998) Żywienie mineralne. In: Biologia świerka pospolitego. PAN Instytut Dendrologii, Bogucki Wydawnictwo Naukowe, Poznań

Frankenberger WTJ, Johanson JB, Nelson CO (1983) Urease activity in sewage sludge-amended soils. Soil Biol Biochem 15:543-551

Friedlová M (2010) The influence of heavy metals on soil biological and chemical properties. Soil Water Res 5(1):21-27

García C, Hernandez MT, Pascual JA, Moreno JL, Ros M (2000) Microbial activity in soils of SE Spain exposed to degradation and desertification processes. Strategies for their rehabilitation. In: Stotzky G, Bollag JM (eds) Soil biochemistry. Marcel Dekker, New York, pp 103-123

Gil-Sotres F, Trasar-Cepeda C, Leiros MC, Seoane S (2005) Different approaches to evaluating soil quality using biochemical properties. Soil Biol Biochem 37:877-887

Huang Y, Kang R, Ma X, Qi Y, Mulder J, Duan L (2014) Effects of calcite and magnesite application to a declining Masson pine forest and strongly acidified soil in Southwestern China. Sci Total Environ 48:469-478

Huber C, Weis W, Göttlein A (2006) Tree nutrition of Norway spruce as modified by liming and experimental acidification at the Höglwald site, Germany from 1982 to 2004. Ann For Sci 63:861-869

ICP-Forest Manual (1998) Manual on methods and criteria for harmonized sampling, assessment, monitoring and analysis of the effects of air pollution on forests. (4th ed.). UN-ECE, Red. Res. Centre for Forestry and Forest Products (BFH)

Januszek K, Błońska E, Wanic T, Dawid A, Warchoł M (2011) Selected properties of soils of spruce stands in the western beskid mts one year after fertilization with dolomite, magnesite and serpentinite. Soil Sci Annu 62(1):44-55

Jonard M, André F, Giot P, Weissen F, Van der Perre R (2010) Thirteen-year monitoring of liming and PK fertilization effects on tree vitality in Norway spruce and European beech stands. Eur J For Res 129:1203-1211

Kakei M, Clifford PE (2002) Short-term of lime application on soil properties and fine-root characteristics for a 9-year-old Sitka spruce plantation growing on a deep peat soil. Forestry 75:37-50

Kreutzer K (1995) Effects of forest liming on soil processes. Plant Soil 168-169:447-470 
Liu JX (2004) Correlative research on the activity of enzyme and soil nutrient in the different types of farmland. Chin J Soil Sci 35(4):20-23

Lorenz K, Preton CM, Feger KH (2001) Long-term effects of liming on microbial biomass and activity and soil organic matter quality $\left({ }^{13} \mathrm{C}\right.$ CPMAS NMR) in organic horizons of Norway spruce forests in Southern Germany. J Plant Nutr Soil Sci 164:555-560

Małek S (2010) Nutrient fluxes in planted Norway spruce stands of different age in Southern Poland. Water Air Soil Pollut 209:45-59

Małek S, Barszcz J, Majsterkiewicz K (2012) Changes in the threat of spruce stand disintegration in the Beskid Śląski and Żywiecki Mts in the years 2007-2010. J For Sci 58(12):519-529

Małek S, Januszek K, Keeton W, Barszcz J, Kroczek M, Błońska E, Wanic T (2014) Preliminary effects of fertilization on ecochemical soil condition in mature spruce stands experiencing dieback in the Beskid Śląski and Żywiecki Mts., Poland. Water Air Soil Pollut 225:1971. doi:10.1007/s11270-014-1971-4

Mijangos I, Pérez R, Albizu I, Garbisu C (2006) Effects of fertilization and tillage on soil biological parameters. Enzyme Microb Tech 40:100-106

Paradelo R, Barral MT (2009) Effect of moisture and disaggregation on the microbial activity of soil. Soil Tillage Res 104(2):317-319

Persson T, Wiren A, Andersson S (1990) Effects of liming on carbon and nitrogen mineralization in coniferous forests. Water Air Soil Pollut 54:351-364

Persson T, Rudebeck A, Wiren A (1995) Pools and fluxes of carbon and nitrogen in 40-year-old forest liming experiments in southern Sweden. Water Air Soil Pollut 85:901-906

Reuss JO, Johnson DW (1986) Acid deposition and the acidification of soils and waters. Ecological studies Publ. 59. Springer, New York

Saarsalmi A, Tamminen P, Kukkola M, Levula T (2011) Effects of liming on chemical properties of soil, needle nutrients and growth of Scots pine transplants. For Ecol Manag 262(2):278285
Saarsalmi A, Tamminen P, Kukkola M (2014) Effects of long-term fertilization on soil properties in Scots pine and Norway spruce stands. Silv Fenn 48(1):1-19

Sikström U (2005) Pre-harvest soil acidification, liming or $\mathrm{N}$ fertilization did not significantly affect the survival and growth of young Norway spruce. Silv Fenn 39(3):341-349

Sinsabaugh RL, Lauber CL, Weintraub MN, Ahmed B, Allison SD, Crenshaw C, Contosta AR, Causack D, Frey S, Gallo ME, Gartner TB, Hobbie SE, Holland K, Keeler BL, Powers JS, Stursova M, Takacs-Vesbach C, Wallenstein MD, Zak DR, Zeglin LH (2008) Stoichiometry of soil enzyme activity at global scale. Ecol Lett 11:1252-1264

Stenberg P, Rautiainen M, Manninen T, Vaipio P, Smolander H (2004) Reduced simple ratio better than NDVI for estimating LAI in Finnish pine and spruce stands. Silv Fenn 38(1):3-14

Tabatabai MA (1994) Soil enzymes. In: Weaver RW, Angle S, Bottomley P, Bezdicek D, Smith S, Tabatabai A, Wollum A (eds) Methods of soil analysis. Part 2. microbiological and biochemical properties. soil science society of America. Madison, WI, pp 775-833

Torbert JLJR, Burger JA (1984) Long-term availability of applied phosphorus to loblolly pine Pinus taeda on a piedmont soil. Soil Sci Soc Am J 48:1174-1178

Viro P (1951) Nutrient status and fertility of forest soil Pine stands. Comunicationes Instituti Forestalis Fenniae 39(4):54

Wyszkowska J, Kucharski J, Jastrzebska E, Hlasko A (2001) The biological properties of the soil as influenced bychromium contamination. Pol J Environ Stud 10:175-183

Xiao-guang J, Chong-sheng G, Guo-hong L, Yu-yu S (2011) Effect of long-term fertilization on soil enzyme activities under different hydrothermal conditions in northeast China. Agric Scie China 10(3):412-422

Zöttl HW (1990) Ernahrung und Dungung der Fichte. Forstw Cbl 109(2-3):130-137 